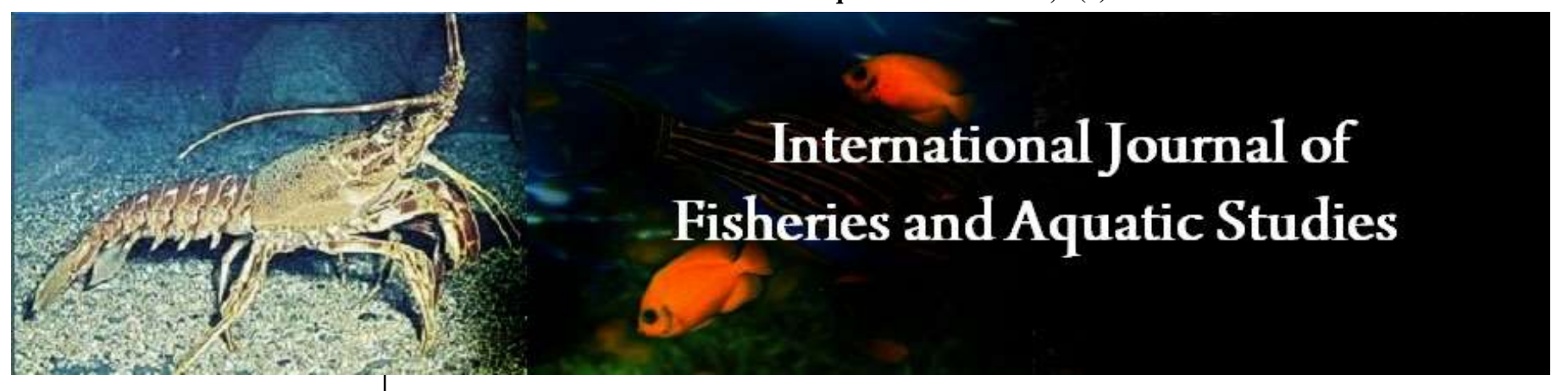

E-ISSN: 2347-5129

P-ISSN: 2394-0506

(ICV-Poland) Impact Value: 5.62

(GIF) Impact Factor: 0.549

IJFAS 2020; 8(6): 49-53

(C) 2020 IJFAS

www.fisheriesjournal.com

Received: 28-09-2020

Accepted: 05-11-2020

Emmy Lilimantik

Lecturer of Fisheries

Agribusiness Studies Program,

Faculty of Fisheries, University

of Lambung Mangkurat,

Banjarmasin, Indonesia

Corresponding Author:

Emmy Lilimantik

Lecturer of Fisheries

Agribusiness Studies Program,

Faculty of Fisheries, University

of Lambung Mangkurat,

Banjarmasin, Indonesia

\section{The fishery marketing channel in Kotabaru regency South Borneo Indonesia}

\section{Emmy Lilimantik}

DOI: $\underline{\text { https://doi.org/10.22271/fish.2020.v8.i6a.2361 }}$

\begin{abstract}
This research was aimed at analyzing the fishery marketing patterns in Kotabaru Regency, South Borneo Indonesia. Analysis employed were (a) marketing channels using snowball sampling method, (b) farmer's share and (c) margin marketing. The results showed that (a) fishery marketing consisted of five channels, (b) price share obtained by producer was ranged from $42 \%$ until $84 \%$ of total price paid by consumers, which showed the marketing system was efficient, and (c) the marketing margin obtained by small trader was larger than that of wholesaler. Meanwhile, profit margin distribution was higher compared to the marketing cost margin distribution. It meant that the profit obtained broker trader was bigger if compared with costs of marketing and production.
\end{abstract}

Keywords: Producer, wholesaler, retailer, marketing channel, farmer's share and margin

\section{Introduction}

The Indonesian Sea has 5.8 million $\mathrm{km}^{2}$ area consisting of $0.3 \mathrm{~km}^{2}$ of territorial sea, $2.95 \mathrm{~km}^{2}$ of archipelagic waters and $2.55 \mathrm{~km}^{2}$ of the Exclusive Economic Zone water ${ }^{[1]}$, with the potential for sustainable marine resource 6,26 million tonnes of catch per year ${ }^{[2]}$. Recently, the amount of fish catches in Indonesian marine waters reaches 5.4 million tonnes per year, it means that there is a chance to increase the total allowable catch, which is 720.000 tonnes per year ${ }^{[3]}$. The Indonesia capture fisheries have the important roles and strategic roles; it can be seen from these three roles ${ }^{[5]}$, which are the source of economis growth, food sources especially animal protein ${ }^{[6]}$, and job providers ${ }^{[7]}$. Fisheries create jobs and act as a "safety net" when other sources of income are failed ${ }^{[8]}$.

Fishery products are decomposed quickly after being caught ${ }^{[9]}$, this is because the water content in the fish's body is $76.00 \%$ causing bacteria to rapidly multiply ${ }^{[10]}$. In addition, other factors such as temperature, availability of oxygen, light, less sanitary and hygienic equipment, mishandling of raw materials can also effect the preservation and freshness of the product ${ }^{[11]}$. These weaknesses are blocking the activities of fishing communities and often cause great losses, especially when the fish production is overflow ${ }^{[12]}$. One of the way to overcome these weaknesses is speed and accuracy in marketing fishery products ${ }^{[13]}$. Each of the delay time means the quality will decrease, part of weight of the fish will also decrease ${ }^{[14]}$, and in the end it will affect the selling price that received by the producers ${ }^{[15,16]}$. Fish marketing is an important factor in delivering fishery products (i.e.catch, cultivation) from producers to the consumers $[17,18]$. Kotabaru regency located in South Borneo province is the center of the biggest sea fishery producer. Sustainable fishery potential in Kotabaru regency reached at capacity of 98.000 tons/year and sea fish, which could be obtained (Maximum Sustainable Yield) was 77.600 tons per year. Those were consisted of many types of fish as follows Scomberromo commersoni 220.5 tons/year, shrimp 105 tons/year, Rastrelliger 150.8 tons/year, Euthynnus affinis 93 tons/year, lobster 96 tons/year, sea weed 447 tons/year as well as sea corals reserves ${ }^{[19]}$. The location of fishermen in Kotabaru Regency are located in several places that far from each other, causing high marketing costs and a weak bargaining position for fishermen in selling the fish that they catch ${ }^{[20]}$. There is a high difference in the price of fresh sea fish between the price in the fisherman area and the final consumers causing the fishermen's to be low ${ }^{[21]}$, besides that most fishermen sell the fish in the middle of the sea to the middlemen inshore, and as a result, collusion can occur between middlemen which is very dentrimental for the fishermen ${ }^{[22]}$. 
These factors made the marketing agencies reduce the prices to the fishermen or increase the prices to the final consumers ${ }^{[23]}$, so that (a) more profits for marketing agencies and (b) fishermen and final consumers not getting the fair price ${ }^{[24]}$. Effective marketing is expected to (a) be able to increase producer income, because the effective and efficient marketing will encourage the increase fishery production and (b) increase purchasing power and consumer satisfaction ${ }^{[25]}$.

\section{Materials and Methods}

\subsection{Research Approach}

Kotabaru regency was chosen as place of work since it is located on the coastal area and is the area whose community depends on fishery activity. Data used was consisted of primary and secondary. The primary data was obtained by survey and interview to respondents adapted from previous work ${ }^{[26]}$. Respondents sample sampling used the method of Simple Random Sampling in which samples were producers and small traders. Meanwhile, snowball sampling technique was employed to obtain sample ${ }^{[27]}$. Secondary data was taken from literature studies and studies of data and information related to both the results of previous studies and other supporting data derived from several publications that already conduct ${ }^{[28]}$, secondary data was collected from references survey and reports of related institutions and was obtained from Fishery Department in South Borneo ${ }^{[29]}$.

\subsection{Marketing Analysis}

Analyses used an approach as follows: the first was analysis of marketing channel, which was qualitative. It employed to know the marketing channel of fish that formed from fishermen (producer) until consumers. Method used in this analysis was snowball sampling whose initial sampling numbered small and then respondents invited their friends joining in this work (sample). If it works, the sample gradually expands likes snowball ${ }^{[30]}$.

The second was a Farmer's Share Analysis, which used a mathematics analysis, or quantitative approach. Since locations of fishermen are in remote areas and are far away from marketing center cause many institutions involved. This condition impacts to small traders (brokers) existence ${ }^{[31]}$. The longer the marketing chain is the higher the cost of marketing that causes the bigger of marketing margin and the farmer obtained profit low [32]. The Farmer's share analysis is formulated following: $\mathrm{Fs}=\mathrm{Pf} / \mathrm{Pr} \times 100 \%{ }^{[33]}$. Where, Fs is Farmer's share; $\mathrm{Pf}$ is the price at producer (fishermen) and $\mathrm{Pr}$ is the price in traders. Previous report, if the share price that received by the farmers/fisherman is higher than $40 \%$, then the marketing system can be said as efficient. ${ }^{[34]}$. The third was the marketing margin analysis that was the difference between the price of fishermen and consumers. The price theory is assumed that seller and buyer directly meet so the price was only determined by bargaining and demand power ${ }^{[35]}$. It is concluded that no difference the price of fishermen and traders, or consumers. Based on a fishery economic research showed that there was a price difference of traders and fishermen, which was called marketing margin ${ }^{[36]}$. The resultant marketing margin is determined by using a formula: $\mathrm{M}=\mathrm{Pr}-\mathrm{Pf}{ }^{[37]}$, where, $\mathrm{M}$ is the marketing margin; $\mathrm{Pr}$ is consumer price and $\mathrm{Pf}$ is fishermen price.

\section{Results and Discussion \\ 3.1 Marketing Channel}

Based on data obtained at a research place showed that the marketing channel of sea fish of fishermen to consumers in Kotabaru shown in Fig.1, describes that $83 \%$ of fishermen sold their fish to collector traders and $16.6 \%$ to offshore traders and then $25 \%$ and $75 \%$ of fish were distributed to companies/exporters and retailer traders, respectively. The $46 \%$ and $53.8 \%$ of fish obtained by offshore traders were distributed to companies/exporters and inter-island traders. The sale of fresh fish from fishermen to consumers only accounted $0.4 \%$ and was carried out in the village whose fishermen and buyers lived together. Sometimes external consumer visited the fishermen village and bought some fish for self-consuming.

Distribution system as shown in Fig. 1 reveals that collector traders were the biggest buyers that is possible since the other marketing institutions capability is limited buying a specific fish ${ }^{[38]}$. Company was only buying an export quality fish (like shrimp), while, inter-island traders a special fish, such as, Euthynnus affinis, Scomberromo commersoni and Rastrelliger ${ }^{[39]}$. In this research, marketing institutions were involved as follow the wholesaler traders, retailer traders and exporter company. Generally, wholesaler traders self-funded product transportation from fishermen villages to big traders and retailers.

The wholesaler traders, generally, have enough capital and trapped fishermen by lending money, or other needs used by fishermen under agreement stipulating that all catchers should be sold to lenders ${ }^{[40]}$. Though credit was handed by lenders under agreement, the fishermen considered that ways was easy and fast process and it could be paid by installment with fish whose the price was previously set by traders. The fishermen just followed the rules and the lower price was not problem because easy and fast treatments given by trader were more important ${ }^{[41]}$.

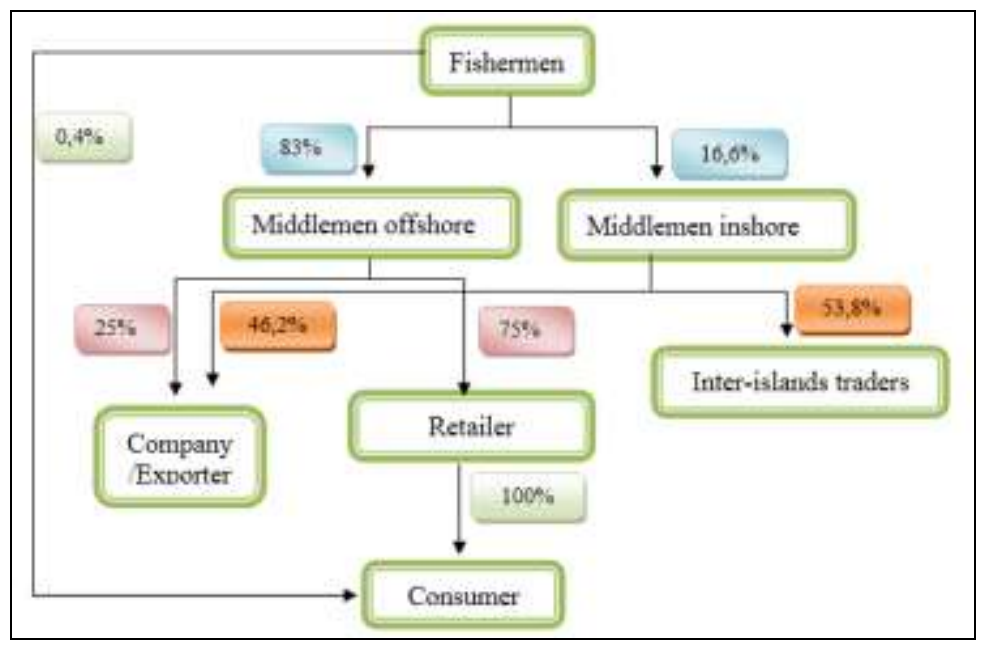

Fig 1: The marketing channel of sea fish in Kotabaru regency 
Retailer traders buy fishery product from wholesaler traders who have related for year and they have corporated under agreement. The fishermen were difficult to turn to other traders since they were known and needed each other. Market concentration was established naturally between fishermen and small traders, collector traders and company. While, the retailer traders did not fund the transportation cost nor took a risk ${ }^{[42]}$. Generally, retailer traders determining the price referred to buying price and expenditure costs that meant if in bargaining process had been getting a profit, the product would be sold. Either company or exporter in purchasing fish acted similar to that of retailer traders to fishermen in which company bounded the small traders by lending money or basic needs (machine, fuels and ice) so collector traders sold fish to big company. In purchasing fishery products, the company has been conditions, which should be fulfilled by small traders, such as the fish was high quality ${ }^{[43]}$.

\subsection{Farmer's Share}

Analysis result of Farmer's Share, or price obtained by farmer is seen in Table 1, which describes that $50 \%$ to $84 \%$ paid by consumers were fishermen shares in which marketing system was efficient.

Table 1: Farmer's Share analysis of fresh fish in Kotabaru regency

\begin{tabular}{|c|c|c|c|c|}
\hline No. & Type of fish & Producer price (Pf) & Consumer price (Pr) & Farmer's Share (\%) \\
\hline 1. & Scomberromo commersoni & 60,315 & 71,740 & 84.000 \\
\hline 2. & Euthynnus affinis & 14,924 & 30,000 & 50.000 \\
\hline 3. & Rastrelliger & 24,966 & 35,000 & 71.000 \\
\hline 4. & Shrimp & 29,750 & 42,395 & 70.000 \\
\hline
\end{tabular}

Source: processed primary data, 2019

From table 1, we can see that the share of prices received by producers ranges from $50 \%$ to $84 \%$ of the price that paid by consumers, this value indicates an efficient marketing system. The amount of the price received by producers is closely related to the marketing system that has been formen between producers and marketing insitutions (i.e. middlemen, retailer) [44]. This is because (a) they want to get a profit without any risk and (b) the average producer has limited production yields, causing them to feel that it is better for them to cooperate with marketing agencies rather than selling it themselves to the retail market. Such condition made the services of middlemen is still needed so that the products can reach to the final consumers ${ }^{[45]}$.

\subsection{Marketing Margin}

Table 2 shows that the amount of marketing margin varies according to the type of the fish; it can be seen from the amount of marketing margin for each different type of fish.
The value of the marketing margin received by retailers is greater than the middlemen, because the marketing costs incurred by the middlemen are greater than the marketing costs incurred by retailers due to the long distances involved in delivering the fishery products ${ }^{[46]}$. In addition, retailers' profits are bigger than middlemen's profit, because middlemen with large sales volumes only take small profit per unit and retailers with small sales volumes take large profits per rupiah costs ${ }^{[47]}$. If it is seen from the amount of fish that being traded, middlemen still get bigger profits than the retailers ${ }^{[48]}$. Overall, from the traders (i.e. middlemen, retailers) point of view, it can be concluded that the distribution of profits is bigger than the distributor of marketing costs. The profit obtained by intermediary traders is higher compared to the amount of marketing costs incurred; this indicates that marketing from the side of mitermediary traders can be said as efficient ${ }^{[49]}$.

Table 2: The marketing margin analysis of fresh fish in Kotabaru regency

\begin{tabular}{|c|c|c|c|c|c|c|c|c|c|}
\hline \multirow[b]{2}{*}{ No. } & \multirow[b]{2}{*}{ Stakeholders } & \multicolumn{2}{|c|}{ Scomberromo commersoni } & \multicolumn{2}{|c|}{ Euthynnus affinis } & \multicolumn{2}{|c|}{ Rastrelliger } & \multicolumn{2}{|c|}{ Shrimp } \\
\hline & & IDR/kg & $\begin{array}{c}\text { Margin } \\
\text { Dist. (\%) }\end{array}$ & IDR/kg & $\begin{array}{c}\text { Margin } \\
\text { Dist. (\%) }\end{array}$ & IDR/kg & $\begin{array}{c}\text { Margin } \\
\text { Dist. (\%) }\end{array}$ & IDR/kg & $\begin{array}{c}\text { Margin } \\
\text { Dist. (\%) }\end{array}$ \\
\hline \multirow[t]{2}{*}{1.} & Producer & & & & & & & & \\
\hline & Sold price & 60,315 & & 14,924 & & 24,966 & & 29,750 & \\
\hline \multirow[t]{6}{*}{2.} & Collector price & & & & & & & & \\
\hline & a. Buying price & 60,315 & & 14,924 & & 24,966 & & 29,750 & \\
\hline & b. Marketing cost & 1,832 & 24 & 2,710 & 18 & 681 & 27 & 2,710 & 21 \\
\hline & c. Sold price & 64,857 & & 22,357 & & 28,357 & & 35,192 & \\
\hline & d. Profit & 2,710 & 16 & 4,723 & 31 & 2,710 & 7 & 2,732 & 22 \\
\hline & Marketing margin & 4,542 & 40 & 7,433 & 49 & 3,391 & 34 & 5,442 & 43 \\
\hline \multirow[t]{6}{*}{3.} & Retailer trader & & & & & & & & \\
\hline & a. Buying price & 64,857 & & 22,357 & & 28,357 & & 35,192 & \\
\hline & b. Marketing cost & 1,861 & 16 & 1,861 & 12 & 1,861 & 19 & 1,861 & 15 \\
\hline & c. Sold price & 71,740 & & 30,000 & & 35,000 & & 42,395 & \\
\hline & d. Profit & 5,022 & 44 & 5,782 & 38 & 4,782 & 48 & 5,342 & 42 \\
\hline & Marketing margin & 6,883 & 60 & 7,643 & 51 & 6,643 & 66 & 7,203 & 57 \\
\hline \multirow[t]{2}{*}{4.} & Consumer price & 71,740 & & 30,000 & & 35,000 & & 42,395 & \\
\hline & Total marketing margin & 11,425 & 100 & 15,076 & 100 & 10,034 & 134 & 12,645 & 100 \\
\hline
\end{tabular}

Source: Processed primary data, 2019

\section{Conclusions}

The sea fishery marketing pattern was analyzed successfully in Kotabaru regency South Borneo introducing marketing channels, snowball sampling method, farmer's share and margin marketing.

It was investigated that the fishery marketing consisted of five patterns in which wholesaler traders was the biggest buyer, while other player was limited. The price obtained by producer was ranged between $50 \%$ and $84 \%$ of that paid by consumers that was indicative the marketing system was efficient.

Comparison of profit margin and the marketing cost margin distributions for all fish, which were traded, showed that the 
profit marginal distribution was higher compared with the marketing cost marginal distribution. It meant that the profit gained by middlemen and processing traders was bigger if compared with the cost of marketing and production. It was an indication that the marketing on broker trader was efficient.

\section{References}

1. Lasabuda R. Regional Development in Coastal and Ocean in Archipelago Perspective of The Republic of Indonesia. Journal Ilmiah Platax. 2013;(I-2):92-101.

2. Budiharsono S. Coastal and Ocean Development Analysis Techniques. Publisher PT. Pradnya Paramitha. Jakarta 2001.

3. Purnomo BH. The Role of Sustainable Capture Fisheries to Support Food Security in Indonesia. Article. Faculty of Agricultural Technology Jember University 2012.

4. Triarso I. Potential and Opportunities for the Development of Capture Fisheries Business in Pantura, Central Java. Journal of Fisheries Technology Science 2012;8(1):65-73

5. Rizal A, Iskandar, Herawati H, Dewanti LP. Potraits and Review: Fisheries and Marine Development Strategy. Unpad Press. Bandung 2018.

6. Sanger CLM, Jusuf A, Andaki JA. Analysis of the Entrepreneurial Orentation of Small-Scale Capture Fishermen with Fishing Tools "JUBI" in Batulubang Village, Lembeh Selatan, Bitung City. Acculturation: Scientific Journal of Fisheries Agribusiness 2019;7(1):1095-1101.

7. Bene C, Macfadyen G, Allison EH. Increasing the Contribution of Small-Scale Fisheries to Poverty Alleviation and Food Security. FAO Fisheries Technical Paper 481. Rome: FAO 2007.

8. Cunningham S. Fishermens' Incomes and Fisheries Management. Research Paper No. 61. Portsmouth: CEMARE. University of Portsmouth 1993.

9. Machena C, Kwaramba R. The Creation of Property Rights to Promote Sustainable Development in Lake Kariba Inshore fishery in Zimbabwe. In K. Remane (Ed.). African Inland Fisheries, Aquaculture and the Environment. London: Fishing News Books 1997, 245254.

10. Adawiyah R. Fish Processing and Peservation. Bumi Aksara Press. Jakarta 2011

11. Widyasari HE. Effect of Preservation Using Picung Seeds (Pangium edule Reinw) Againts Freshness and Safe Fresh Mackerel Fish (Rastrelliger brachysoma). Bogor Agricultural Institute 2006.

12. Begum R, Akter T, Barman PP, Marine SS, Hossain MM. Potential for development of marine fish marketing systems in Chittagong District of Bangladesh. Journal of the Sylhet Agricultural University 2014;1(2):247-252.

13. Rokeya JA, Ahmed SS, Bhuiyan AS, Alam MS Marketing system of native and exotic major carps of Rajshahi District. Bangladesh Journal of Fisheries 1997;20(1-2):99-103.

14. Rahman, Ahmadi, Mahreda ES. Marketing channels of marine fish in Banjarmasin fishing port, Indonesia. International Journal of Fisheries and Aquatic Research 2019;4(3):15-22.

15. Lilimantik E. The Marketing of Fresh Sea Fish in Tanah Laut Regency, South Kalimantan. Proceedings of the National Seminar on Agribusiness and Rural Economic Development III. Trunojoyo University. Madura, East Java 2016.

16. Anindita R, Baladina N. Marketing of Agricultural Products. Andi Press, Yogyakarta 2017.
17. Lilimantik E. Spatial Equilibrium of Tilapia (Oreochromis niloticus bleeker) market in South Borneo Province, Indonesia. European Journal of Business and Management 2013;5:5.

18. Husen MA. Fish marketing system in Nepal: Present status and Future prospects. International Journal of Applied Science and Biotechnology 2019;7(1):1-5.

19. Ministry of Maritime and Fisheries, Kotabaru Regency. Book of Materials Fishing Equipment-1. Department of Maritime and Fisheries, Kotabaru 2018.

20. Tomek WG, Robinson KL. Agricultural Product Price. Third Printing Cornell University Press Ithaca and London 1977.

21. Mahreda ES. Marketing Efficiency of Fresh Sea Fish in South Kalimantan. Doctoral Dissertation of Agricultural Socio-Economics, Agricultural Science. Gajah Mada University, Yogyakarta 2002.

22. Lilimantik E. Marketing of Fishery Products. Unlam Press Publisher, Kalimantan Selatan 2007.

23. Azzaino. Introduction to Agricultural Trading. Agriculture Departement. Agricultural Socio-Economic Sciences. IPB, Bogor 1982.

24. Hanafiah dan Saefuddin. Fishery Product Trading. University of Indonesia, Jakarta 1996.

25. Sudiono, A. Agricultural Marketing. Muhammadiyah Malang University Press 2004.

26. Arikunto. Research Prosedur, A Practical Approach Rhineka Cipta, Jakarta 2006.

27. Nazir. Research Method. 6th edition. Ghalia Indonesia Publisher. Bogor 2011.

28. Neuman WL. Qualitative and Quantitative Approach. Social Research Methods. Boston: Allyn and Bacon. Keegan, W.J., 2002. Global Marketing Management. Pearson Education, Delhi 2003, p 194.

29. Bungin B. Quantitaive Research Data Analysis. Jakarta: Raja Grafindo 2006.

30. Sugiarto et al. Sampling Technique. Gramedia Pustaka Utama. Jakarta 2003.

31. Dağtekin M. Fishery production and marketing structure in Trabzon (MSc Thesis). Çukurova University, Adana, Turkey 2010.

32. Shahi HM, Zeratkish Y, Foroughi V. Factors affecting Trout marketing in Kohgiloye and Boyer Ahmad Province of Iran. Journal of Food Agriculture and Environment 2012;10(1):248-250.

33. Kohls RL Uhl. Marketing of Agricultural Products. A Prentice-Hall Upper Saddle River, New Jersey 2002.

34. Saravanapandeeswari V, Vanitha B. Producer's share in consumer Rupee in the marketing of Banana, Theni District. International Journal of Current Science Research 2017;3(7):1311-1320.

35. Limbong WH. Dan Sitorus P. Introduction to Agricultural Commerce, Departement of AgricultureSocial Economic Sciences, Faculty of Agriculture IPB. Bogor 1987.

36. Flowra FA, Bashar AHM, Jahan KSN, Samad MA, Islam MM. Fish marketing system and socio economic status of Aratdars in Natore and Rajshahi, Bangladesh. Journal of Our Nature 2012;10(1):34-43.

37. Kohl RL Dan Downey WD. Marketing of Agricultural Product. Macmillan International editions 1972.

38. Jadhav G, Borgave S. Marine Fish Marketing System and Distribution Channels in India: A Literature Review. International Journal of Research and Analytical Reviews (IJRAR) 2019;6:2.

39. Madugu AJ, Edward A. Marketing and Distribution Channel of Processed Fish in Adamawa State, Nigeria. Global Journal of Management and Business Research 
2011;11:4.

40. Ali MM, Rahman M, Hossain Y, Rahman Z, Hossen A, Naser AM, et al. Fish marketing system in southern Bangladesh: recommendations for efficient marketing. Our Nature 2014;12(1):28-36.

41. Edoge ED. Determinants of Choice of Distribution Channels by Fish Farmers in Ughelli North Local Government Area of Delta. Asian Journal of Agriculture and Food Sciences 2014;2:5.

42. Hossain A, Al-Asif Zafar A, Hossain T, Alam S, Islam A. Marketing of fish and fishery products in Dinajpur and Livelihoods of the fish retailers. International Journal of Fisheries and Aquatic Studies 2015;3(1):86-92.

43. Kumar BG, Ravisankarb T, Sureshc R, Bhattad R, Vimalab D, Kumaranb M, et al. Lessons from innovative institutions in the marketing of fish and fishery products in India. Agricultural Economics Research Review 2010;23:495-504.

44. Hakansson. International marketing and purchasing of industrial goods. University of Uppsala, Sweden 1982.

45. Huger LB, Hirenath KC. Efficiency of alternative channels in marketing of vegetables in Belgaum City - A comparison. Indian Journal of Agricultural Economics 1984;34(3).

46. Abidin Z. Marketing Efficiency of Economically Important Marine Fish in Malang Regency of East Java, Indonesia International Review of Management and Marketing 2018;8(3):14-18.

47. Husen MA. Fish marketing system in Nepal: Present status and Future prospects. International Journal of Applied Science and Biotechnology 2019;7(1):1-5.

48. Hussain SA, Badar H, Khokhar SB. Market intermediaries and their marketing margins for Inland Fish - A case study of Lahore District. International Journal of Agriculture and Biology 2003;5(1):73-76.

49. Natarajan Narayanakumar, Harshan. Marketing costs, margins and efficiency of domestic marine fish marketing in Kerala. Indian Journal of Fisheries 2014;61(2):97-102. 